\title{
Entre imagen y pensamiento ${ }^{1}$
}

Una parte importante de los esfuerzos en la disciplina arquitectónica se destinan hoy en día a bienales, publicaciones y elaboración de presentaciones. En este contexto embriagado por las imágenes, y ante el inminente repliegue del render, las reflexiones de Hidalgo vuelven a situar a la representación arquitectónica en perspectiva. Porque antes que seducir por una apariencia, las imágenes en arquitectura son herramientas, capaces de comunicar un modo de construir al tiempo que informar ciertas experiencias: reflexión y percepción simultáneas. ¿La imagen es nada? No creo. Palabras clave: Dibujo arquitectónico, teoria de la arquitectura.

A significant amount of effort in contemporary architecture is invested in organizing biennials, publications and presentations. In this context of intoxication with images, where renders are about to become obsolete, Hidalgo's reflections put architectural representation in perspective. Because, more than an instrument of seduction, architectural images are tools that communicate ways of constructing while also informing certain experiences: reflection and perception together. Do images amount to nothing? I certainly don't think so.

Keywords: Architectural drawing, theory of architecture.

Lo que intentaré en las siguientes líneas es dar una perspectiva histórica a los temas que hoy nos convocan. Creo que es posible pensar la historia de la arquitectura y sus medios de representación, a la luz de lo que entiendo ha sido un debate permanente; me refiero a ése que se establece entre imagen y pensamiento. Dos instancias ideológicas referidas a la representación arquitectónica que se han disputado, sin tregua, su dirección rectora. $\mathrm{Y}$ esto, me interesa señalarlo a propósito de tres momentos bien precisos e identificables.

El primero de ellos, que podríamos calificar de inicio, o comienzo, de una tradición, queda determinado por la famosa carta que Rafael de Urbino enviara al Papa León X, en 1519, a propósito del levantamiento de algunos edificios de la antigüedad, en la que establece las bases de un cuerpo disciplinar que se irá consolidando en el tiempo.

En efecto, en esta carta Rafael propone por primera vez un sistema específico para la representación de la arquitectura, consistente en mostrar tres aspectos esenciales de los edificios, a saber: la planta, el corte (o pared de dentro), y la fachada (o pared externa). Podemos advertir aquí el primer indicio del debate que hemos querido comentar, y que se desarrolla entre pensamiento e imagen, o lo que es lo mismo, entre reflexión intelectual y percepción visual.

Hablamos, pues, de la necesidad de establecer con precisión los límites que deslindan el modo de representar propio de los arquitectos, y el modo de representar de los pintores; una necesidad que podríamos decir, en el Rafael pintor se vuelve perentoria. En otras palabras, es la necesidad de distanciarse de la sistematización de la aproximación visual al mundo propuesta por Masaccio y Brunelleschi y que, más tarde, teorizara Alberti con sus fundamentos del todo matemáticos para lo que hoy conocemos como perspectiva. Frente a ello, Rafael privilegiará, en cambio, un modo intelectual y abstracto que, desde ese instante en adelante, se asociará a la "correcta" representación de la arquitectura.

Sin duda que, para comprender y explicarse el origen de esta necesidad, hay que remitirse a los nuevos ideales de racionalidad que surgen desde el humanismo de Erasmo o de Lorenzo Valla. Son los ideales que, finalmente, derivaron en la necesidad de mostrar no sólo cómo se vería el edificio una vez concluido cuando se lo mirara desde un punto vista dado, sino de referir las relaciones entre sus partes; justamente, esas relaciones que permanecen ocultas a la mirada del hombre. Claramente, el ideal platónico de señalar y poner valor en lo subyacente queda perfectamente encarnado en esta aspiración. Un segundo momento lo podemos advertir cuando estos mismos principios elevados por Rafael son puestos en tela de juicio. Nos referimos a ese momento de quiebre que fue la Ilustración. Un momento en el cual, no en vano, la historiografía reciente ha querido ver los orígenes de la arquitectura moderna: hablemos, por ejemplo, de las historias contadas por Kenneth Frampton o Peter Collins.

En efecto, la arquitectura de Etienne-Louis Boullée hecha literalmente de imágenes, arquitectura que atiende a los sentidos, o de la "sin razón" como también se la ha denominado, es la manifestación de replantear el problema de definir los límites en que se mueve la representación arquitectónica.

Y nos encontramos con que Boullée quiere llevarla, nuevamente, a un terreno esencialmente pictórico, donde la supremacía es la de la imagen, amparada en un fundamento concretamente visual. De allí el rol privilegiado que asume en su obra el tema de las luces y de las sombras, y el énfasis que se pone en proporcionar dimensiones colosales tendientes a descolocar a un observador que se toma por sorpresa. ¿Quién es el hombre del siglo de las luces, sino aquel que, privado de la facultad de comprender, sólo le queda como opción el experimentar?

No es extraño, por tanto, que el mismo Boullée encabece su texto "Arquitectura. Ensayo sobre el arte", con la célebre frase de Correggio: "Ed io anche son pittore". Éste, "yo también soy pintor", es el que nos alerta sobre el intento de recuperar la dimensión pictórica contenida en la arquitectura. Estamos ante la puesta en valor de su vertiente artística, que se concibe por encima de los contenidos funcionales y prácticos, propios del mundo de la construcción. Asimismo, es también el cuestionamiento del andamiaje intelectual que levantara Rafael, es decir, la intención de hacer prevalecer lo aparente por sobre lo subyacente, conscientes y tolerantes de aquellos aspectos del hombre que permanecían ocultos: la aspereza de sus sentidos que lo ataban al ser íntimo que llevamos dentro. Por último, y ya a inicios del siglo XX, creemos identificar el momento de una posible conciliacióny distensión de este debate. Conciliación que, pensamos, queda perfectamente representada con la aparición en escena de CharlesÉdouard Jeanneret, Le Corbusier.

Tocamos el caso de Jeanneret porque, precisamente, es este debate el que marcó fuertemente el desarrollo de lo que fue su formación como arquitecto. A lo largo de más de una década (1910-1920), su interés por una u otra disciplina se alternó, aunque, sin lugar a dudas, ya por aquella época el predominio de su actividad como arquitecto era mucho más relevante. Pues bien, si en este dilema hemos hablado de una posible conciliación, ésta vendrá de la mano de un pintor: Amédée Ozenfant, quien, en 1917, aparecerá en la vida de Jeanneret para poner en ella, al parecer, un orden definitivo.

En efecto, es Ozenfant quien alienta a Jeanneret para que insista con la pintura al óleo, aquella que ya tenía casi en el olvido, si acaso la conocía con anterioridad a este encuentro; es Ozenfant quien lo invita a participar en su proyecto de L'Esprit Nouveau; y es en el desarrollo de este proyecto que lo inicia en la fe del Purismo, rebautizándolo con el seudónimo de Le Corbusier, el profeta de la nueva arquitectura. Será como Le Corbusier, que Jeanneret rubricará sus artículos sobre arquitectura en la revista L'Esprit Nouveau, dejando su apellido paterno, únicamente, para figurar al pie de sus creaciones pictóricas.

¿Qué hay aquí, nuevamente, sino el deseo de deslindar, lacerantemente, aquello que le compete al mundo de la pintura con respecto al de la arquitectura? Un deseo que, de momento, sólo es posible concretar al costo de escindir una personalidad.

Como todos sabemos, el ya viejo Le Corbusier supo conciliar esta dicotomía tanto en un plano trascendente como en la vida cotidiana. Así es como repartía sus actividades diarias pintando en su taller por las mañanas, y dejando para la tarde su quehacer arquitectónico en el estudio de la rue de Sevrès. Como también sabemos, aquello que por las mañanas experimentaba sobre una tela, con colores y pinceles, por las tardes lo vertía en plantas y cortes: abstracciones austeras, algebrizaciones áridas a la vista, como las llamó en "Vers une Architecture". Sin duda se puede concluir que en ello había un esfuerzo para concretar plenamente su actividad como creador, transformando las imágenes de sus sueños matinales, en el fundamento que surgía poderoso desde el fondo de su pensamiento. ARQ 